\title{
Faktor-faktor yang mempengaruhi kemampuan kognitif pada lansia obesitas di Indonesia
}

Factors related to cognitive capacity on Indonesian elderly with obesity

Yoseph Leonardo Samodra ${ }^{1}$, Neni Trilusiana Rahmawati ${ }^{2}$, Sumarni ${ }^{3}$

${ }^{1}$ Fakultas Kedokteran Universitas Kristen Duta Wacana

${ }^{2}$ Departemen Anatomi, Embriologi, dan Antropologi, Fakultas Kedokteran, Kesehatan Masyarakat, dan Keperawatan Universitas Gadjah Mada

${ }^{3}$ Fakultas Kedokteran, Kesehatan Masyarakat, dan Keperawatan Universitas Gadjah Mada

\begin{abstract}
Background: Elderly (>60 years old) population is growing in Indonesia. It is important to prevent degradation of cognitive capacity by risk factor identification and treatment. Objective: To identify the relationship between anthropometric status and cognitive capacity on elderly population. Method: This is an analysis of The Fifth Wave of the Indonesia Family Life Survey (IFLS5) data with cross-sectional design. Anthropometric status is consisted of: body weight, body height, body mass index (BMI), knee height, upper arm length, waist circumference, hip circumference, and waist-hip ratio (WHR). Cognitive capacity is measured by modified telephone survey of cognitive status (TICS). Chi-Square and Mann-Whitney test are used for bivariate analysis, logistic regression is used for multivariate analysis. Results: Variables with significant relationship to cognitive capacity are body weight ( $p=0.0002)$, body height ( $p=0.0001)$, knee height ( $p=0.0387)$, upper arm length $(p=0.0114)$, age $(p=0.011)$, sex $(p=0.014)$, and history of hypercholesterolemia $(p=0.003)$. Logistic regression shows that body height, age, and history of hypercholesterolemia are simultaneously affecting cognitive capacity. Conclusion: There is significant relationship between body height, body weight, upper arm length, knee height, and cognitive capacity on elderly population with obesity.
\end{abstract}

KEY WORDS: anthropometry; cognitive; elderly; obesity

\section{ABSTRAK}

Latar belakang: Jumlah dan proporsi penduduk Indonesia yang tergolong lanjut usia (60 tahun ke atas) semakin bertambah dari waktu ke waktu. Perlu dilakukan pencegahan penurunan kemampuan kognitif melalui identifikasi dan penanganan faktor risiko. Tujuan: Penelitian ini bertujuan untuk mengetahui hubungan status antropometri terhadap kemampuan kognitif pada populasi lanjut usia obesitas. Metode: Analisis data sekunder dengan desain cross-sectional. Data dari penelitian The Fifth Wave of the Indonesia Family Life Survey (IFLS5) yang dilakukan pada September 2014 hingga September 2015. Status antropometri yang dianalisis yaitu berat badan, tinggi badan, indeks massa tubuh (IMT), tinggi lutut, panjang lengan atas, lingkar pinggang, lingkar pinggul, dan rasio lingkar pinggang terhadap lingkar pinggul (RLPP). Kemampuan kognitif diukur dengan telephone survey of cognitive status (TICS) yang dimodifikasi. Analisis bivariat menggunakan uji Chi-Square dan Mann-Whitney, dilanjutkan dengan regresi logistik untuk analisis multivariat. Hasil: Variabel yang memiliki hubungan bermakna terhadap kemampuan kognitif adalah berat badan $(\mathrm{p}=0,0002)$; tinggi badan $(\mathrm{p}=0,0001)$; tinggi lutut $(\mathrm{p}=0,0387)$; panjang lengan atas $(\mathrm{p}=0,0114)$; usia $(\mathrm{p}=0,011)$; jenis kelamin $(\mathrm{p}=0,014)$; dan riwayat hiperkolesterolemia $(\mathrm{p}=0,003)$. Hasil regresi logistik menyatakan variabel yang secara bersama-sama mempengaruhi kemampuan kognitif adalah tinggi badan, usia, dan riwayat hiperkolesterolemia. Simpulan: Tinggi badan, berat badan, panjang lengan atas, dan tinggi lutut berhubungan bermakna terhadap kemampuan kognitif pada populasi lanjut usia obesitas.

KATA KUNCI: antropometri; kognitif; lansia; obesitas

\section{PENDAHULUAN}

Jumlah penduduk Indonesia yang tergolong lanjut usia (60 tahun ke atas) dan proporsinya terhadap seluruh penduduk Indonesia semakin bertambah dari waktu ke waktu. Pada sensus penduduk tahun 2010 didapatkan penduduk lanjut usia sebanyak 18.015.162 orang atau

Korespondensi: Yoseph Leonardo Samodra, Fakultas Kedokteran Universitas Kristen Duta Wacana, Jl. Wahidin Sudirohusodo 5-25, Yogyakarta, Indonesia, Telp+6285298060969,e-mail: yosephsamodra@gmail.com 
7,6\% dari seluruh penduduk (1). Badan Pusat Statistik memproyeksikan bahwa pada tahun 2025 penduduk lanjut usia di Indonesia akan mencapai 33.695.800 orang (11,8\% dari seluruh penduduk) dan pada tahun 2035 akan meningkat menjadi 48.198 .700 orang atau $15,8 \%$ dari seluruh penduduk (2).

Jumlah penduduk lanjut usia yang semakin meningkat dapat disertai meningkatnya jumlah penderita demensia. Pencegahan penurunan kemampuan kognitif melalui identifikasi dan penanganan faktor risiko menjadi penting dalam menghadapi peningkatan jumlah penduduk lanjut usia (3). Prevalensi demensia pada lanjut usia di Daerah Istimewa Yogyakarta (DIY) pada tahun 2016 mencapai 20,1\% (4). Belum ada data prevalensi demensia secara nasional untuk Indonesia, tetapi Alzheimer's Disease International memperkirakan pada tahun 2015 terdapat 556.000 penderita demensia di Indonesia (5).

Prevalensi penduduk laki-laki dewasa obesitas pada tahun 2013 sebanyak 19,7 persen yang lebih tinggi dari tahun 2007 (13,9\%) dan tahun 2010 (7,8\%). Prevalensi obesitas perempuan dewasa 32,9 persen, naik drastis dari tahun 2007 (13,9\%) dan tahun 2010 (15,5\%) (6). Status gizi seseorang diketahui memiliki hubungan dengan penurunan kemampuan kognitifnya (3). Salah satu metode penilaian status gizi ialah melalui pengukuran antropometri. Penelitian yang meneliti hubungan status antropometri terhadap kemampuan kognitif belum banyak dilakukan di Indonesia, terutama yang spesifik pada populasi lanjut usia obesitas. Berdasarkan uraian di atas, perlu dilakukan penelitian tentang hubungan status antropometri terhadap kemampuan kognitif pada populasi lanjut usia obesitas menggunakan data IFLS5.

\section{BAHAN DAN METODE}

Penelitian ini adalah penelitian observasional berupa analisis data sekunder dengan desain penelitian cross-sectional menggunakan data The Fifth Wave of the Indonesia Family Life Survey (IFLS5) yang dilakukan pada September 2014 hingga September 2015. Data IFLS5 mencakup 16.204 rumah tangga dan 50.148 individu. Teknik pengambilan subjek menggunakan metode total sampling. Subjek penelitian adalah populasi penelitian yang memenuhi kriteria inklusi (memiliki data umur, jenis kelamin, pengukuran antropometri, kemampuan kognitif, nilai indeks massa tubuh (IMT) $25 \mathrm{~kg} / \mathrm{m}^{2}$ atau lebih) dan tidak termasuk dalam kelompok eksklusi (data kemampuan kognitif tidak lengkap, pernah didiagnosis masalah pada otak, retardasi mental, atau autisme).

Variabel bebas dalam penelitian ini adalah status antropometri yang mencakup berat badan, tinggi badan, IMT, tinggi lutut, panjang lengan atas, lingkar pinggang, lingkar pinggul, dan rasio lingkar pinggang terhadap lingkar pinggul (RLPP). Variabel terikat pada penelitian ini adalah kemampuan kognitif. Variabel luar yang diteliti adalah adalah usia, jenis kelamin, riwayat hipertensi, riwayat diabetes mellitus, dan riwayat hiperkolesterolemia.

Pengumpulan data IFLS5 menggunakan kuesioner baku berbasis komputer (computer-assisted personal interview system atau CAPI) yang dilakukan oleh enumerator terstandar. Pada pengumpulan data yang memerlukan pengukuran dilakukan dengan prosedur pengukuran yang terstandar dan menggunakan alat ukur yang terkalibrasi (7).

Berat badan pada IFLS5 diukur dalam posisi berdiri, berpakaian minimal, dan menggunakan timbangan digital Camry model EB1003. Pengukuran tinggi badan dilakukan dalam posisi berdiri menggunakan papan ukur Seca model 213 (7). Indeks massa tubuh dihitung menggunakan rumus berat badan dalam kilogram dibagi dengan kuadrat dari tinggi badan dalam meter. Pada IFLS5 dilakukan pengukuran tinggi lutut menggunakan papan ukur Seca model 213 dan panjang lengan atas sebagai proksi untuk tinggi tubuh. Pengukuran lingkar pinggang dan lingkar pinggul dilakukan menggunakan pita ukur (7). Rasio lingkar pinggang terhadap lingkar pinggul (RLPP) adalah perbandingan lingkar pinggang terhadap lingkar pinggul untuk menggambarkan lemak abdominal seseorang (8). Rumus yang dipakai adalah lingkar pinggang dalam sentimeter dibagi dengan lingkar pinggul dalam sentimeter.

Kemampuan kognitif adalah tingkat kecerdasan yang diperlukan untuk memecahkan masalah di kehidupan sehari-hari (9). Pada IFLS5 digunakan pertanyaan yang mengacu pada Telephone Survey of Cognitive Status (TICS) yang dimodifikasi sesuai dengan standar Health and Retirement Study (HRS) (7). Hasilnya 
dikategorikan menjadi dua berdasarkan perbandingan jumlah benar terhadap nilai rerata yaitu kurang (jumlah benar $<$ nilai rerata) dan cukup (jumlah benar $\geq$ nilai rerata). Usia adalah jangka waktu sejak subjek dilahirkan hingga saat pengambilan data dalam satuan tahun yang dihitung berdasarkan ulang tahun terakhir (7). Riwayat hipertensi, riwayat diabetes mellitus, dan riwayat hiperkolesterolemia adalah keadaan subjek yang pernah didiagnosis kondisi-kondisi tersebut oleh dokter maupun petugas kesehatan lainnya.

Data dianalisis menggunakan software Stata ${ }^{\circledR}$ 13 dengan uji statistik Mann-Whitney dan Chi-Square untuk analisis bivariat, sedangkan analisis multivariat menggunakan uji regresi logistik. Penelitian ini telah mendapatkan surat ethical clearance dengan nomor: KE/ FK/0432/EC/2017 dari Medical and Health Research Ethics Committee (MHREC) Fakultas Kedokteran Universitas Gadjah Mada.

\section{HASIL}

Pemilihan subjek dalam penelitian ini dimulai dari seluruh responden IFLS5 yang berusia 60 tahun ke atas yang berjumlah 4.007 individu, tetapi hanya 3.742 individu yang memiliki data jenis kelamin. Sebanyak 3.585 individu yang memiliki data pengukuran antropometri dan hanya 2.865 individu yang memiliki data kemampuan kognitif. Berdasarkan IMT, sebanyak 2.132 individu memiliki IMT kurang dari $25 \mathrm{~kg} / \mathrm{m}^{2}$ sedangkan hanya sebanyak 733 individu yang memiliki IMT lebih dari atau sama dengan $25 \mathrm{~kg} / \mathrm{m}^{2}$. Jumlah subjek penelitian berkurang menjadi 627 individu karena 105 individu tidak memiliki data lengkap kemampuan kognitif dan 1 individu terdiagnosis salah satu kondisi kesehatan yang tercantum dalam kriteria eksklusi. Alur pemilihan sampel penelitian ini dapat dilihat secara skematis pada Gambar 1. Karakteristik subjek penelitian dapat dilihat pada Tabel 1.

Analisis bivariat variabel numerik terhadap variabel kemampuan kognitif dilakukan menggunakan uji Mann-Whitney yang hasilnya dapat dilihat pada Tabel 2. Uji Mann-Whitney dipilih karena sebaran data numerik tidak normal pada dua kelompok yang dibagi berdasarkan kemampuan kognitif. Analisis bivariat variabel numerik terhadap kemampuan kognitif menunjukkan bahwa yang memiliki hubungan bermakna terhadap kemampuan kognitif adalah berat badan, tinggi badan, tinggi lutut, panjang lengan atas, dan usia $(\mathrm{p} \leq 0,05)$.

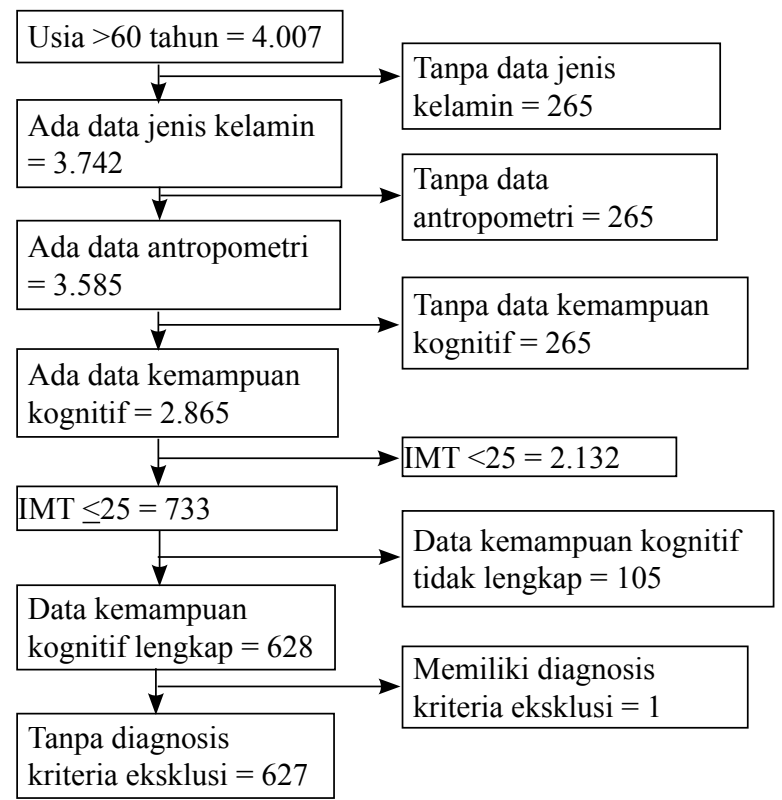

Gambar 1. Skema pemilihan sampel

Tabel 1. Karakteristik subjek penelitian

\begin{tabular}{lrr}
\hline Karakteristik & $\begin{array}{r}\text { n (\%), rerata } \pm \text { SD, atau } \\
\text { median }(\text { min-maks) }\end{array}$ \\
\hline Berat badan $(\mathrm{kg})$ & 64,2 & $(45,5-99,6)$ \\
Tinggi badan $(\mathrm{cm})$ & 151,1 & $(132,0-176,2)$ \\
IMT $\left(\mathrm{kg} / \mathrm{m}^{2}\right)$ & 27,4 & $(25,0-42,2)$ \\
Tinggi lutut $(\mathrm{cm})$ & 47,2 & $(36,7-99,6)$ \\
Panjang lengan atas $(\mathrm{cm})$ & 33,4 & $(12,8-43,2)$ \\
Lingkar pinggang $(\mathrm{cm})$ & 96,9 & $(73,6-140,4)$ \\
Lingkar pinggul $(\mathrm{cm})$ & 101,5 & $(76,3-143,7)$ \\
RLPP & 1,0 & $(0,7-1,4)$ \\
Usia (tahun) & 64 & $(60-87)$ \\
Kemampuan kognitif & & $13,8 \pm 4,7$ \\
$\quad$ Kurang & & $298(47,53)$ \\
$\quad$ Cukup & & $329(52,47)$ \\
Jenis kelamin & & \\
$\quad$ Laki-laki & & $216(34,45)$ \\
$\quad$ Perempuan & & $411(65,55)$ \\
Riwayat hipertensi & & \\
$\quad$ Ada & & $251(40,03)$ \\
$\quad$ Tidak ada & & $376(59,97)$ \\
Riwayat diabetes mellitus & & \\
$\quad$ Ada & & $75(11,96)$ \\
Tidak ada & & $552(88,04)$ \\
Riwayat hiperkolesterolemia & & \\
Ada & & $93(14,83)$ \\
Tidak ada & & \\
\hline
\end{tabular}


Yoseph Leonardo Samodra, et al: Faktor-faktor yang mempengaruhi kemampuan kognitif pada lansia obesitas di Indonesia

Tabel 2. Hubungan variabel numerik dengan kemampuan kognitif

\begin{tabular}{|c|c|c|c|c|}
\hline \multirow{2}{*}{$\begin{array}{c}\text { Variabel } \\
\text { (median (min-maks)) }\end{array}$} & \multicolumn{3}{|c|}{ Kemampuan kognitif [median (min-maks)] } & \multirow[b]{2}{*}{$\mathbf{p}$} \\
\hline & & $\begin{array}{l}\text { urang } \\
1=298)\end{array}$ & $\begin{array}{c}\text { Cukup } \\
(n=329)\end{array}$ & \\
\hline Berat tubuh & 63,0 & $(45,5-99,5)$ & $65,0 \quad(46,2-99,6)$ & $0,001 * *$ \\
\hline Tinggi tubuh & 149,6 & $(132,0-172,1)$ & $152,7(132,4-176,2)$ & $0,001 * *$ \\
\hline $\mathrm{IMT}^{1}$ & 27,4 & $(25,0-42,2)$ & $27,4 \quad(25,0-41,0)$ & 0,551 \\
\hline Tinggi lutut & 46,9 & $(39,2-55,0)$ & $47,6 \quad(36,7-99,6)$ & $0,039 *$ \\
\hline Panjang lengan atas & 33,1 & $(24,1-41,8)$ & $33,5 \quad(12,8-43,2)$ & $0,011^{*}$ \\
\hline Lingkar pinggang & 97,0 & $(73,6-140,4)$ & $96,8 \quad(76,2-128,0)$ & 0,671 \\
\hline Lingkar pinggul & 101,6 & $(76,3-132,2)$ & $101,5 \quad(89,0-143,7)$ & 0,189 \\
\hline $\mathrm{RLPP}^{2}$ & 1,0 & $(0,7-1,4)$ & $1,0 \quad(0,7-1,1)$ & 0,066 \\
\hline Usia & 64,0 & $(60,0-87,0)$ & $63,0 \quad(60,0-82,0)$ & $0,011 *$ \\
\hline
\end{tabular}

$*=\mathrm{p} \leq 0,05 ; * *=\mathrm{p} \leq 0,01 ;{ }^{1} \mathrm{IMT}=$ indeks massa tubuh; ${ }^{2} \mathrm{RLPP}=$ rasio lingkar pinggang pinggul

Tabel 3. Hubungan variabel kategori dengan kemampuan kognitif

\begin{tabular}{|c|c|c|c|c|c|c|c|}
\hline \multirow{3}{*}{ Variabel } & \multicolumn{4}{|c|}{ Kemampuan kognitif } & \multirow{3}{*}{ OR } & \multirow{3}{*}{$95 \% \mathrm{CI}$} & \multirow{3}{*}{$\mathbf{p}$} \\
\hline & \multicolumn{2}{|c|}{ Kurang } & \multicolumn{2}{|c|}{ Cukup } & & & \\
\hline & $\mathbf{n}$ & $\%$ & $\mathbf{n}$ & $\%$ & & & \\
\hline \multicolumn{8}{|l|}{ Jenis kelamin } \\
\hline Laki-laki & 88 & 40,7 & 128 & 59,3 & \multirow{2}{*}{0,66} & \multirow{2}{*}{$0,46-0,93$} & \multirow{2}{*}{$0,014 *$} \\
\hline Perempuan & 210 & 51,1 & 201 & 48,9 & & & \\
\hline \multicolumn{8}{|l|}{ Riwayat hipertensi } \\
\hline Ada & 114 & 45,4 & 137 & 54,6 & \multirow{2}{*}{0,87} & \multirow{2}{*}{$0,62-1,21$} & \multirow{2}{*}{0,387} \\
\hline Tidak ada & 184 & 48,9 & 192 & 51,1 & & & \\
\hline \multicolumn{8}{|c|}{ Riwayat diabetes mellitus } \\
\hline Ada & 30 & 40,0 & 45 & 60,0 & \multirow{2}{*}{0,71} & \multirow{2}{*}{$0,42-1,19$} & \multirow{2}{*}{0,164} \\
\hline Tidak ada & 268 & 48,6 & 284 & 51,4 & & & \\
\hline \multicolumn{8}{|c|}{ Riwayat hiperkolesterolemia } \\
\hline Ada & 31 & 33,3 & 62 & 66,7 & \multirow{2}{*}{0,50} & \multirow{2}{*}{$0,30-0,81$} & \multirow{2}{*}{$0,003 * *$} \\
\hline Tidak ada & 267 & 50,0 & 267 & 50,0 & & & \\
\hline
\end{tabular}

Chi-Square test digunakan untuk menganalisis hubungan variabel kategori terhadap variabel kemampuan kognitif karena seluruh sel memiliki nilai expected lebih dari 5. Tabel 3 menunjukkan bahwa yang memiliki hubungan bermakna terhadap kemampuan kognitif adalah jenis kelamin dan riwayat hiperkolesterolemia $(\mathrm{p} \leq 0,05)$. Jenis kelamin dan riwayat hiperkolesterolemia terhadap kemampuan kognitif memiliki OR $<1,0$. Hal ini menunjukkan bahwa jenis kelamin laki-laki dan adanya riwayat hiperkolesterolemia adalah faktor protektif terhadap rendahnya kemampuan kognitif.

Analisis regresi logistik dilakukan untuk mengetahui faktor apa saja yang secara bersama-sama berpengaruh terhadap rendahnya kemampuan kognitif, dengan menyertakan variabel yang pada analisis bivariat memiliki nilai $p$ kurang dari 0,25 yaitu berat badan, tinggi badan, tinggi lutut, panjang lengan atas, lingkar pinggul, usia, jenis kelamin, riwayat diabetes mellitus, dan riwayat hiperkolesterolemia yang hasilnya dapat dilihat pada Tabel 4. Variabel yang tersisa adalah tinggi badan, usia, dan riwayat hiperkolesterolemia yang merupakan variabel yang secara bersama-sama mempengaruhi rendahnya kemampuan kognitif. Goodness-of-fit test dilakukan untuk melihat nilai kalibrasi dari model regresi logistik ini, dan didapatkan hasil $\mathrm{p}=0,44$ yang menunjukkan bahwa model regresi logistik ini terkalibrasi dengan baik. 
Tabel 4. Regresi logistik

\begin{tabular}{lcccccc}
\hline \multirow{2}{*}{ Variabel } & \multicolumn{3}{c}{ Tahap awal } & \multicolumn{3}{c}{ Tahap akhir } \\
\cline { 2 - 7 } & Koefisien & OR & p & Koefisien & OR & p \\
\hline Berat badan & $-0,0151$ & 0,99 & 0,429 & & & \\
Tinggi badan & 0,0418 & 1,04 & 0,056 & 0,0361 & 1,04 & $<0,001$ \\
Tinggi lutut & 0,0005 & 1,00 & 0,986 & & & \\
Panjang lengan atas & 0,0041 & 1,00 & 0,912 & & & \\
Lingkar pinggul & 0,0219 & 1,02 & 0,194 & & & \\
Usia & $-0,0491$ & 0,95 & 0,006 & $-0,0473$ & 0,95 & 0,006 \\
Jenis kelamin & $-0,0896$ & 0,91 & 0,737 & & & \\
Riwayat diabetes mellitus & $-0,2213$ & 0,80 & 0,392 & & & \\
Riwayat hiperkolesterolemia & $-0,6816$ & 0,51 & 0,005 & $-0,7283$ & 0,48 & 0,002 \\
Konstanta & $-3,6599$ & 0,03 & 0,254 & $-1,6826$ & 0,19 & 0,400 \\
\hline
\end{tabular}

\section{BAHASAN}

Proses menua melibatkan berbagai perubahan fisiologis yang tampak sebagai penurunan berat badan, tinggi badan, dan massa otot, serta adanya peningkatan massa lemak (8). Hal ini menunjukkan bahwa pengukuran antropometri dapat menjadi salah satu metode penilaian status gizi yang utama pada populasi lansia. Temuan bahwa kelompok dengan kemampuan kognitif kurang memiliki berat badan yang lebih kecil sejalan dengan hasil penelitian pada lansia di Swedia. Penelitian tersebut menemukan bahwa penderita gangguan fungsi kognitif memiliki berat badan yang lebih kecil dibandingkan dengan lansia yang tidak mengalami penurunan kemampuan kognitif. Hal ini mungkin dipengaruhi oleh penurunan nafsu makan yang terkait dengan penurunan kemampuan kognitif akan memperburuk asupan seharihari sehingga memicu penurunan berat badan yang tidak diinginkan. Selain itu, demensia juga diketahui berhubungan dengan disfagia yang dapat secara langsung menurunkan asupan makanan (10). Berat badan kurang dari normal (IMT $<18,5 \mathrm{~kg} / \mathrm{m}^{2}$ ) baik pada laki-laki maupun perempuan diketahui berhubungan dengan penurunan kesejahteraan fisik, sosial, dan mental (8).

Tinggi badan diketahui sebagai salah satu hasil pengukuran antropometri yang dapat menggambarkan proses tumbuh kembang sejak dari kandungan, yang dapat mempengaruhi fase kehidupan selanjutnya. Faktor-faktor yang diketahui mempengaruhi tinggi badan seseorang mencakup genetik dan lingkungan sosioekonomi (yang berhubungan erat dengan pemenuhan kebutuhan gizi).
Hubungan tinggi badan dengan kemampuan kognitif sejalan dengan hasil penelitian pada lansia di Korea Selatan yang menemukan bahwa tinggi badan yang lebih kecil berisiko lebih tinggi untuk terjadinya penurunan kemampuan kognitif (11).

Nilai IMT yang tidak berbeda pada kedua kelompok sesuai dengan hasil penelitian di Tiongkok yang menyatakan bahwa obesitas total yang diukur dengan IMT saja tidak memiliki efek bermakna pada penurunan kemampuan kognitif (3). Namun, penelitian di Malaysia menemukan bahwa lansia penderita gangguan kognitif ringan memiliki nilai IMT yang lebih besar dibandingkan dengan lansia tanpa penurunan kemampuan kognitif(12). Hubungan obesitas total dengan penurunan kemampuan kognitif memang masih kontroversi. Penelitian di Brazil menunjukkan bahwa IMT berhubungan dengan gangguan kognitif pada kelompok lansia muda (usia 60-69 tahun) sedangkan pada kelompok yang lebih tua hubungan ini menghilang (13). Mekanisme hubungan antara IMT dengan penurunan kemampuan kognitif masih belum jelas. Indeks massa tubuh yang rendah dapat disebabkan oleh penurunan berat badan sebagai prekursor demensia sedangkan IMT yang tinggi dapat dihasilkan oleh penambahan massa otot maupun massa lemak. Massa bebas lemak yang lebih tinggi dapat berperan menurunkan risiko demensia pada populasi lansia. Kemungkinan lainnya adalah IMT yang besar disebabkan oleh peningkatan timbunan lemak selain di area abdominal (3). Massa lemak yang lebih banyak di tungkai lansia ditemukan berhubungan dengan perbaikan metabolisme glukosa dan menurunkan risiko terjadinya 
diabetes mellitus yang dapat berperan dalam penurunan risiko terjadinya gangguan kognitif (14).

Perlu diperhatikan bahwa sulit mendapatkan hasil pengukuran tinggi badan yang akurat pada lansia. Masalah ini mungkin dapat diatasi dengan menggunakan tinggi lutut atau pengukuran proksi tinggi tubuh yang lain, tetapi perlu evaluasi lebih lanjut terhadap nilai prognostik dari penggunaan metode proksi ini (8). Pengukuran tinggi lutut diharapkan dapat memberikan gambaran tinggi badan yang lebih akurat, baik melalui proyeksi tinggi badan menggunakan rumus tertentu atau langsung dicari hubungannya dengan variabel yang diinginkan. Tinggi lutut diketahui secara langsung memiliki hubungan dengan penurunan kemampuan kognitif (15). Hasil analisis bivariat diperoleh nilai tinggi lutut dan panjang lengan atas yang lebih besar dan bermakna secara statistik pada kelompok dengan kemampuan kognitif cukup. Temuan ini sejalan dengan hasil penelitian di Amerika Serikat yang menemukan bahwa tinggi lutut yang lebih besar berkaitan dengan risiko demensia yang lebih rendah. Namun, penelitian tersebut tidak mencantumkan analisis yang melibatkan tinggi badan sehingga tidak bisa membandingkan kaitan tinggi badan dan tinggi lutut dengan penurunan kemampuan kognitif (15).

Hasil studi di Inggris menemukan bahwa tinggi lutut paling kuat berhubungan dengan riwayat konsumsi air susu ibu dan asupan energi saat seseorang berusia empat tahun. Hubungan ini menunjukkan betapa besar pengaruh lingkungan dan diet pada masa awal kehidupan yang tampak nyata pada periode pertumbuhan tulangtulang panjang pada lengan dan kaki yang paling cepat (16), meskipun diketahui bahwa pertumbuhan tulang maupun tinggi badan secara keseluruhan dipengaruhi juga oleh faktor genetik dari kedua orangtua. Di samping itu, juga mempertimbangkan bahwa kekurangan gizi pada masa awal kehidupan, paparan terhadap toksin dari lingkungan, atau hal-hal lain juga mempengaruhi kecerdasan, fungsi kognitif, dan kerentanan terhadap timbulnya demensia (15). Normalnya panjang lengan atas akan berkorelasi dengan tinggi lutut dan tinggi badan karena pertumbuhan lengan dan kaki terjadi secara bersama-sama (17) sehingga mendukung hasil penelitian ini yang menyatakan panjang lengan atas ditemukan berhubungan dengan kemampuan kognitif.
Berdasarkan hasil analisis bivariat diketahui bahwa usia yang lebih tua berhubungan bermakna dengan nilai kemampuan kognitif yang lebih kecil. Sejalan dengan hasil penelitian di Brazil yaitu penderita gangguan kognitif memiliki rata-rata usia 71,1 tahun sedangkan yang tidak mengalami gangguan kognitif rata-rata usianya 68,4 tahun (13). Kejadian demensia akan semakin bertambah seiring bertambahnya usia. Peningkatannya bersifat eksponensial, yaitu menjadi dua kali lipat setiap sekitar 5 tahun, dan akan terus meningkat bahkan untuk mereka yang berusia sangat tua (18). Hal ini dibuktikan oleh hasil penelitian di Yogyakarta yaitu pada umur 60an tahun ditemukan 1 dari 10 lansia mengalami demensia, kemudian pada usia 70an tahun ditemukan 2 dari 10 lansia terkena demensia. Lebih lanjut, ketika memasuki usia 80an tahun ditemukan 4-5 dari 10 lansia terkena demensia dan saat memasuki usia 90an tahun ditemukan 7 dari 10 lansia mengalami demensia (4).

Hasil analisis juga menunjukkan tidak adanya hubungan antara lingkar pinggang, lingkar pinggul, maupun RLPP terhadap kemampuan kognitif, meskipun tampak kecenderungan nilai yang lebih besar pada kelompok dengan kemampuan kognitif kurang. Obesitas sentral (yang diukur menggunakan lingkar pinggang dan RLPP) masih diperdebatkan peranannya sebagai faktor risiko independen terhadap penurunan kemampuan kognitif. Pada kejadian diabetes mellitus, resistensi insulin, penyakit jantung koroner, stroke, dan angka mortalitas dapat diketahui bahwa obesitas sentral sebagai faktor risiko yang lebih kuat dan independen dibandingkan dengan obesitas total (3). Temuan pada penelitian ini bertentangan dengan penelitian di Malaysia yang menemukan bahwa lansia penderita gangguan kognitif ringan memiliki nilai lingkar pinggang yang lebih tinggi dibandingkan dengan lansia tanpa penurunan kemampuan kognitif(12). Penelitian di Brazil menemukan bahwa lingkar pinggang dapat memprediksikan kejadian demensia yaitu lansia dengan obesitas sentral lebih mungkin 5,6 kali menderita demensia (19). Ukuran lingkar panggul selain berguna untuk menghitung RLPP juga dapat memberikan informasi tambahan mengenai massa otot gluteofemoral dan struktur tulang panggul (3). Penelitian pada lansia di Swedia menemukan bahwa penderita gangguan fungsi kognitif memiliki RLPP 
yang lebih rendah dibandingkan dengan lansia yang tidak mengalami penurunan kemampuan kognitif (10). Sebaliknya, pada lansia di Tiongkok ditemukan nilai lingkar pinggang dan RLPP yang makin tinggi akan meningkatkan prevalensi gangguan kognitif (3).

Sebanyak $65,55 \%$ subjek penelitian ini berjenis kelamin perempuan, hampir dua kali lipat dari subjek laki-laki (34,45\%). Hasil yang serupa ditemukan pada penelitian berbasis populasi di Brazil yang 61,4\% subjek penelitiannya adalah perempuan (13). Namun, hal ini tidak menggambarkan keadaan di Indonesia. Jumlah lansia perempuan memang lebih banyak daripada lakilaki, yaitu 10,77 juta lansia perempuan dibandingkan 9,47 juta lansia laki-laki. Proporsi ini ketika dipersentasekan hasilnya adalah lansia perempuan hanya 53,2\% dari seluruh lansia di Indonesia (20). Hasil penelitian ini menyimpulkan bahwa jenis kelamin laki-laki menjadi faktor protektif terhadap penurunan kemampuan kognitif. Artinya, jenis kelamin perempuan lebih berisiko mengalami penurunan kemampuan kognitif. Temuan ini sejalan dengan penelitian yang menyatakan bahwa jenis kelamin tidak berpengaruh signifikan terhadap terjadinya demensia vaskular pada populasi lansia, tetapi ketika dikaitkan dengan obesitas maka didapatkan pengaruh jenis kelamin perempuan lebih kuat terhadap kejadian demensia vaskular (21).

Hubungan antara berat badan dengan penurunan kemampuan kognitif dapat terjadi melalui beberapa faktor risiko potensial lainnya. Hipertensi dan diabetes mellitus memperburuk perfusi otak dan merupakan faktor risiko utama terjadinya penyakit serebrovaskular, stroke, dan demensia (22). Namun, pada penelitian ini riwayat hipertensi dan diabetes mellitus tidak bermakna secara statistik terhadap berkurangnya kemampuan kognitif dan efek yang ditunjukkan adalah efek protektif.

Hipertensi diketahui dapat memberikan efek negatif pada daya ingat seseorang. Obesitas dan hipertensi adalah faktor risiko terjadinya aterosklerosis sehingga patut diduga bahwa aterosklerosis adalah salah satu mekanisme utama untuk menjelaskan bagaimana hipertensi dapat menurunkan kemampuan kognitif pada penderita obesitas. Hal ini diperkuat dengan korelasi tingkat keparahan demensia dengan tingkat keparahan aterosklerosis (23). Durasi dan tingkat keparahan diabetes mellitus pada seseorang memberikan pengaruh besar pada patofisiologi gangguan kognitif pada penderita diabetes mellitus. Durasi yang lama berhubungan dengan penyakit makrovaskular serebral, infark serebral klinis, maupun infark subklinis yang dapat menurunkan kemampuan kognitif. Tingkat keparahan berkaitan dengan kejadian hiperglikemia kronik yang akan meningkatkan terjadinya gangguan mikrovaskular serebral, kerusakan neuronal, atrofi otak, dan gangguan kognitif(24). Hiperkolesterolemia pada usia pertengahan berhubungan dengan peningkatan risiko gangguan kognitif, demensia, maupun penyakit Alzheimer (25). Tingginya kadar kolesterol dapat memicu aterosklerosis yang menurunkan perfusi otak dan meningkatkan kecepatan neurodegenerasi melalui pengaruhnya terhadap pembentukan beta amiloid, yang ketika menjadi plak dalam jumlah berlebihan dapat berkaitan dengan kejadian penyakit Alzheimer (26).

Pada penelitian ini, riwayat hipertensi, diabetes mellitus, dan hiperkolesterolemia menunjukkan efek protektif. Hal ini kemungkinan karena yang mendiagnosis adalah petugas kesehatan maka penderita mendapatkan terapi dan edukasi yang sesuai sehingga ketika riwayat penyakit yang dijadikan variabel dalam analisis akan menghasilkan efek protektif. Hal ini didukung oleh penelitian yang menyatakan bahwa edukasi adalah cara yang efektif untuk merubah perilaku pengobatan pasien hipertensi ke arah yang lebih baik. Seiring perubahan perilaku kepatuhan pasien ke arah yang positif, maka semakin besar juga penurunan tekanan darah (27). Demikian pula penelitian lain yang menyatakan bahwa terdapat hubungan positif antara tingkat pengetahuan pasien tentang diabetes mellitus dengan kendali kadar glukosa darah (28). Target tata laksana hiperkolesterolemia dapat dicapai melalui konseling yang memegang peranan penting dalam memberikan pengetahuan dan motivasi untuk melakukan perubahan gaya hidup (29).

\section{SIMPULAN DAN SARAN}

Status antropometri yang berhubungan bermakna terhadap kemampuan kognitif pada populasi lanjut usia obesitas yaitu berat badan, tinggi badan, tinggi lutut, dan panjang lengan atas. Hubungan status antropometri 
terhadap kemampuan kognitif juga dipengaruhi oleh faktor lain yaitu usia, jenis kelamin, dan riwayat hiperkolesterolemia.

Pemerintah diharapkan dapat meningkatkan kesejahteraan lansia terutama dalam pemeliharaan status gizi dan kemampuan kognitif yang baik. Pengelolaan berat tubuh dan pengendalian kadar kolesterol diharapkan dapat memberikan manfaat pada kemampuan kognitif dan status kesehatan secara keseluruhan. Pemeriksaan kesehatan dan pengukuran antropometri sebaiknya dilakukan pada semua lansia agar dapat memberikan gambaran mengenai jumlah lansia yang berisiko mengalami penurunan kemampuan kognitif.

\section{UCAPAN TERIMA KASIH}

Penulis mengucapkan terima kasih kepada RAND Corporation atas akses data dan dokumen penunjang IFLS5.

\section{Pernyataan konflik kepentingan}

Penulis tidak memiliki konflik kepentingan dalam penyusunan naskah ini.

\section{RUJUKAN}

1. Cakrabawa D, Hakim M, Hasanah L, editors. Statistik penduduk 1971-2015. Jakarta: Pusat Data dan Sistem Informasi Pertanian, Sekretariat Jenderal, Kementerian Pertanian Republik Indonesia; 2014.

2. Badan Pusat Statistik. Proyeksi penduduk Indonesia 20102035. Jakarta: Badan Pusat Statistik; 2013.

3. Cui GH, Guo HD, Xu RF, Jiang GX, Chen SD, Cheng Q. The association of weight status with cognitive impairment in the elderly population of a Shanghai suburb. Asia Pac J Clin Nutr. 2013;22(1):74-82.

4. Suriastini N, Turana Y, Witoelar F, Supraptilah B, Wicaksono T, Dwi E. Angka prevalensi demensia: perlu perhatian kita semua. Policy Brief. Yogyakarta: SurveyMETER; 2016.

5. Prince M, Comas-Herrera A, Knapp M, Guerchet M, Karagiannidou M. World alzheimer report 2016: improving healthcare for people living with dementia. London: Alzheimer's Disease International; 2016.

6. Balitbang Kemenkes RI. Riset kesehatan dasar: Riskesdas 2013 Jakarta: Kemenkes RI; 2013.
7. Strauss J, Witoelar F, Sikoki B. The Fifth Wave of the Indonesia Family Life Survey (IFLS5): Overview and Field Report. Santa Monica: RAND Corporation; 2016.

8. Sánchez-García S, García-Peña C, Duque-López M, JuárezCedillo T, Cortés-NúñezA, Reyes-Beaman S. Anthropometric measures and nutritional status in a healthy elderly population. BMC Public Health. 2007;7(2):1-9.

9. Osterlund L. Wisdom in the counseling relationship. Jesuit Higher Edu. 2014; 3(2): p. 74-84.

10. Gavriilidou N, Pihlsgård M, Elmståhl S. Anthropometric reference data for elderly Swedes and its disease-related pattern. Eur J Clin Nutr. 2015;69(9):1066-75.

11. Quan S, Jeong J, Kim D. The relationship between height and cognitive function among community-dwelling elderly: Hallym Aging Study. Epidemiol Health 2013;35:e2013002.

12. Won H, Manaf Z, Ludin A, Omar M, Razali R, Shahar S. The cut-off values of anthropometric variables for predicting mild cognitive impairment in Malaysian older adults: a large population based cross-sectional study. Clin Interv Aging. 2017;12:275-82.

13. Castro-Costa É, Peixoto S, Firmo J, Uchoa E, Lima-Costa $\mathrm{M}$. The association between nutritional status and cognitive impairment in Brazilian community-dwelling older adults assessed using a range of anthropometric measures - the Bambui Study. Dement Neuropsychol. 2013;7(4):403-9.

14. Choi SI, Chung D, Lim JS, Lee MY, Shin JY, Huh JH, et al. Relationship between regional body fat distribution and diabetes mellitus: 2008 to 2010 Korean National Health and Nutrition Examination Surveys. Diabetes Metab J. 2017;41(1):51-9.

15. Huang T, Carlson M, Fitzpatrick A, Kuller L, Fried L, Zandi P. Knee height and arm span: a reflection of early life environment and risk of dementia. Neurology. 2008;70:181826.

16. Wadsworth M, Hardy R, Paul A, Marshall S, Cole T. Leg and trunk length at 43 years in relation to childhood health, diet and family circumstances; evidence from the 1946 national birth cohort. Int J Epidemiol. 2002;31:383-90.

17. Huang W, Lei X, Ridder G, Strauss J, Zhao Y. Health, height, height shrinkage, and SES at older ages: evidence from China. Am Econ J Appl Econ. 2013;5(2):86-121.

18. James B, Schneider J. Increasing incidence of dementia in the oldest old: evidence and implications. Alzheimer's Research \& Therapy 2010;2:9.

19. Brito WA, Mendes L, Sales MM, Neto JB, Brito CJ, Grigoletto MEdS, et al. Cognitive profile associated with functional and anthropometric aspects in elderly. Rev Andal Med Deporte. 2016;9(4):154-9.

20. Badan Pusat Statistik. Statistik penduduk lanjut usia 2014. Jakarta: Badan Pusat Statistik; 2015. 
21. Beydoun M, Beydoun H, Wang Y. Obesity and central obesity as risk factors for incident dementia and its subtypes: a systematic review and meta-analysis. Obes Rev. 2008;9(3):204-18.

22. Novak V. Cognition and hemodynamics. Curr Cardiovasc Risk Rep. 2012;6:380-96.

23. Friedman JI, Wallenstein S, Moshier E, Parrella M, White $\mathrm{L}$, Bowler S, et al. The effects of hypertension and body mass index on cognition in schizophrenia. Am J Psychiatry. 2010;167:1232-9.

24. Roberts R, Geda Y, Knopman D, Teresa J, Christianson B, Pankratz V, et al. Duration and severity of diabetes are associated with mild cognitive impairment. Arch Neurol. 2008;65(8):1066-73.

25. Hughes T, Ganguli M. Modifiable midlife risk factors for late-life cognitive impairment and dementia. Curr Psychiatry Rev. 2009;5(2):73-92.
26. Wreksoatmodjo BR. Beberapa kondisi fisik dan penyakit yang merupakan faktor risiko gangguan fungsi kognitif. CDK. 2014;41(1):25-32.

27. Susanto Y, Alfian R. Perbaikan perilaku dan tekanan darah pasien hipertensi di RSUD Dr. H. Moch. Ansari Saleh Banjarmasin setelah pemberian leaflet edukasi hipertensi dan terapinya. Jurnal Ilmiah Manuntung. 2015;1(2):140-4.

28. Perdana A, Ichsan B, Rosyidah D. Hubungan tingkat pengetahuan tentang penyakit DM dengan pengendalian kadar glukosa darah pada pasien DM Tipe II di RSU PKU Muhammadiyah Surakarta. Biomedika. 2013;5(2):17-21.

29. Aurora R, Sinambela A, Noviyanti C. Peran konseling berkelanjutan pada penanganan pasien hiperkolesterolemia. J Indon Med Assoc. 2012;62(5):194-201. 